\title{
A Critical Exposition of Madukakism as a Theory of Being Human in Contemporary Africa
}

\author{
Enyimba Maduka
}

Department of Philosophy, University of Calabar, Calabar, Nigeria

Copyright $\mathrm{C} 2019$ by authors, all rights reserved. Authors agree that this article remains permanently open access under the terms of the Creative Commons Attribution License 4.0 International License

\begin{abstract}
In our world today, what is meant to be human is shrouded in mystery as a result of two major factors. The first being globalization and its attendant Information Communication Technology (ICT). The second having to do with the universal drive towards economic achievements and material acquisition. Following these, the essence, worthiness and self-authenticity of the human person is almost eroded. This paper presents Madukakism as a philosophy of being human in contemporary Africa. It makes the claim that, the idea of Madukakism when imbibed by all and sundry, will restore human dignity and worth as well as foster global peace. The philosophical methods of conversationalism, exposition, conceptual clarification and deduction were employed to show that Madukakism is drawn from the word Madukaku, which is an Igbo concept that represents, explicates and exposes the true nature of human being. Madukaku connotes the quality and value, which the being "human" possesses as against other existing beings. Following the idea of Madukaku, the notion of human being, humanhood, personhood or humanity consist in the quality, value, worth or importance attached or attributed to a person over and above other things. The paper attempts to defend this view by presenting arguments to show that the (Igbo) African, places more value on a person than anything else and this is evident in their naming tradition among other things. It also argues that the terms "human being", as well as Madukaku, are combinations of two words, each of which when broken down are synonymous in meaning and signification. Moreover, "being" metaphysically refers to anything that exists whether visible or invisible, spiritual or physical; and humans are part of the existing things. Hence, the paper presents Madukakism as the authentic basis for (humanness) being human in (Igbo) African worldview.
\end{abstract}

Keywords Madukaku, Madukakism, Being Human, Africa (Igbo) Worldview

\section{Introduction}

Ifeanyi Menkiti and Kwame Gyekye have articulated different notions of being human in African thought. While recognizing the merit of some of their propositions, this paper has gone further to present the position that the concrete nature of being human in Africa is encapsulated in the idea of Madukaku, which is that a person or being is human because he/she is worth more in quality and essence than other (beings) things. Menkiti had argued in his paper "Person and Community in African Traditional Thought", that in the African view, it is the community which defines the person as person, not some isolated static quality of rationality, will or memory [1984,172]. The argument against Menkiti is that whether within or outside the community, a person is rightly be called a person by virtue of his/her worthness, value or importance over other things. Personhood is not what one has to work for or acquire. It is rather inherent in one's ontological nature. Thus, whether the community recognizes it or not, a person remains a person because of the possession of intrinsic worth or value over other creations.

Rejecting Menkiti's view of the community determination of the personhood of a person, Kwame Gyekye presents a normative view of personhood from the Akan perspective. According to him, though a person may be described as communitarian by virtue of being born into an existing community, yet such a community does not determine his humanity. Instead he/she remains a person by virtue of the morality of his/her conduct. In other words, personhood is for Kwame, defined in terms of moral qualities [1992, 109-110]. Kwame's normative conception of the human person appears to be lopsided as it does not consider other essential aspects of the personhood of a person. Thus, it is argued that personhood is the intrinsic ontological virtue of a person that distinguishes him/her as a human being. Being human is an expression of the intrinsic, ontological worth of someone over other beings as embodied in the concept of Madukaku, which forms the bedrock of Madukakism as a philosophy of being human.

The method of conversationalism is deployed to 
converse with other scholars and authors on the notion of personhood. The approach of conceptual clarification is employed to explicate and expose the meaning of Madukaku and Madukakism, while employing deduction to arrive at the conclusion that Madukaku is the basis of being human in contemporary Africa.

This paper is both practically and theoretically significant, in that it aids in solving the problem of misguided self and the search for self-identity or authenticity which are at the root of racial bigotry, and crisis of human relations in the globe. The fact, that an embrace of Madukakism as a philosophy of being human, restores man's dignity and worth and fosters global peace, justifies this research.

\section{The Notion of Madukaku}

The concept of Madukaku is a combination of two distinct Igbo words and one Igbo phrase. These are "Madu", "aku" and "Ka" respectively. The most appropriate English rendition of these concepts are; "human", "wealth" and "is greater than". These translate into "human is greater than wealth". Wealth here can refer to anything else outside the human person. In fact, non-human entities or objects constitutes what can be called wealth. Wealth also include such material acquisitions as; money or finances, houses, cars, social, political, religious and economic status etcetera. This is why the concept of Madukaku (human is greater than wealth) is seen as the embodiment of what it entails to be a human person. Madukaku connotes the essence of being human in that it expresses the intrinsic worth of the being called human. Uzukwu defines human being as "Mmadi," meaning "beauty that is" [1982,195]. Closely related to this aesthetic description of the human person, is Chimakonam and Lucky's assertion that, "Mmadu" ought to relate with one another and other existing reality in order to bring out the beauty of life $[2015,270]$. In other words, for them "Mma""ndu" simply means the beauty of life. In an attempt to show that contemporary African society seems to have derailed from upholding human dignity and therefore have lust touch of what it really means to be human, Ejiogu Amaku rhetorically questions thus:

How do we explain the contemporary preference of money and wealth to human life, such that a human person can be mercilessly kidnapped, held in the bush for days and often killed if a financial demand is not met with?... [2014,4].

In response to this dehumanizing situations in present day Africa, Ejiogu Amaku makes a case for an authentic pan-African humanism whose major aim is the happiness of the human person. For him, education is the basis for an advancement of Pan-African humanism [2014, 251-301]. Similarly, Ike Odimegwu decries the fact that African notion of personhood has not be given the attention it deserves, and has been somehow occluded by the bland assertion of communalism that is now fast turning into a cliché [2008,ix]. He thus, presents his theory of integrative personhood which he believes has great relevance to human beings. According to the theory of integrative personhood, a person perceives and presents himself/herself as the enduring self-present of being constituted in the unity of individuality and communality by the dialogic of presenting [2008,104-135].

What Odimegwu means here is that personhood in Africa is inclusive of a person's individuality and his being a member of the community. This is what defines personhood from the perspective of Odimegwu's integrationism. This present study perceives this as amounting to Menkiti's, Mbiti's as well as Gyekye's idea of personhood which the theory of Madukakism disagrees with. This will be shown in subsequent section.

Considering the relevance of the idea of these scholars and others like Chielozona Eze [1998,27-48], Emmanuel Edeh. [1985,100], Iroegbu [1995,351], to the idea of Madukaku, this work proposes a return to the ideals and values of Igbo notion of being human as encapsulated in the concept of Madukaku as the authentic basis of being human in contemporary African. This is the theory of Madukakism which is projected in this work.

\section{Madukakism as a Theory of Being Human in Contemporary Africa}

For the Igbo speaking people of Eastern Nigeria, West Africa, where the word is drawn from, Madukaku is used to express the value placed on humans above other existing things. For this sect of African people, importance, worth, value, essence and high quality are attached or attributed to a human person over and above other things. According to the Igbo thought system, life cannot subsist without the human person. If the human person is removed from the surface of the earth, the universe becomes empty, having no meaning. In other words, it is humans that give meaning and worth to life forces and other aspects of human existence. This explains why the Igbos of West Africa believe that, no matter how wealthy and highly placed one may be, without a human interactions such a person has lost the meaning and essence of life. Thus, life becomes meaningful because of the existence of humans in the universe. Whereas other things in the universe cannot deploy humans, it is only human beings that have the capacity to use every other existing things, thereby adding meaning and worth to them. What money and other material things cannot do, a human can do them.

This idea of Madukaku as expressed in the worldview of the Igbos is made more explicit through their naming tradition. Within the Igbo cosmos, names are given consciously and purposefully in other to express the intrinsic worth attached to the human person and to life 
generally. At this point, a conceptual analysis of some of these names will expose further the philosophy behind Madukaku. The name, Madubisi is another variant of Madukaku. "Madu" here refers to "human" "bu" refers to "is" and "isi" implies "head". In otherwords "Madubuisi", means, "human is the head". By implication, human is not subservient to any other, he/she is the head, and not the tail. $\mathrm{He} / \mathrm{she}$ is in charge and supreme. Another name that reflects the essence and intrinsic worth of the human person that readily comes to mind is "Madubueze". It means "man is king". Other names include; "Maduakolam" (let no human lack in my life or May I not Lack a human in my life) and "Madubuike" (human is strength). In otherwords, there are certain things want cannot do by his/herself alone, but with fellow humans around, you receive strength to do them."Maduforo" (human remains when all is lost). This means if one has lost everything but human life remains, then he/she still has something worth. "Madukamkpa" (human is more important).

Others include "Madubuchiibeya" (humans are God to his fellow) Onunwa [1991, 69]. "Nwakego" (a child is more precious than money); "Nwabueze (a child is king), "Nwakanma" (a child is better than anything else); "Nwabuihe" (a child is light); "Ndukauba" (human life is greater than riches) and "Ndukaku" (human life is greater than wealth). All these and many other names which underscore the philosophy behind "Madukaku" is summarized in the Igbo proverb that says; "Onye nwere madu ka onye nwere Ego" which is interpreted to mean, "He who has somebody (human person) is greater and better than he that has only money or wealth" The truth implied in this maxim is that, there are certain things which money or riches may not do for he that has it, but only a human may, with a human, money may then become useful and meaningful. In the same vein, there are many things that wealth, riches or money may not buy, but only a human person may bring it or cause it to happen or take place in somebody's life. Such things include; happiness, joy, peace, love and many more.

Thus, Madukaku is the basis of being human in Africa and the world over. It is to be worth more than wealth or any possession or material things. Consequently, Madukaku rejects colonialism, slavery or any form of dehumanizing of the human person. It also forbids man's inhumanity to man. Madukaku underscores all other views on human person as subsistent to the quality and value of being greater than wealth or material acquisition. All these as embedded in the idea of Madukaku have been articulated to formulate "Madukakism" as the philosophy of being human. Madukakism therefore, connotes the essence of humanhood, personhood, humanity, human personality, humanness and indeed being human.

Udobata Onunwa in his "The Individual and Community in African Traditional Religion and Society", seems to lend credence to the above claim. After a careful exposition and criticism of the effect of community or group domination on the individual person, Udobata summarizes thus: While not the lord of the universe in Igbo cosmology, man believes himself to be at the center of the universe, where the pressures and influences of all other things converge and operate. Man is then important [1994, 258].

Indeed, if the human person is at the center of the universe and its activities, then a person's importance, worth and place in the scheme of things in the universe cannot be undermined. Thus, for Madukakism the human is supreme. In fact, as the center piece of the pressures and influences of other beings in the cosmos, the human person is a force to reckon with, which goes to say that, "the society, community or universe is, because the human person is". Thus, the protagorean dictum that "man is the measure of all things" Stumpf [1994, 29] becomes significant here. This idea projects the philosophy and theory of Madukakism. On the contrary John S. Mbiti's dictum that, "I am because we are and because we are I am" [1974,158], is antithetical to the idea of Madukaku as the basis of being human in Africa and as such against the foundation of the philosophy of Madukakism. By implication, what J. S. Mbiti means is that man's security and importance can be located within his own king group which makes him aware of himself. In other words, without the group or community interest or consciousness, the individual ceases to exist and to have meaning.

It is pertinent to mention at this point that on the basis of Mbiti's aphorism, Ifeanyi Menkiti elaborated his own idea of personhood. In a paper with the title "Person and Community in African Traditional Thought", Menkiti avers that "in the African view, it is the community which defines the person as person, not some isolated static quality of rationality, will or memory. Moreover, personhood for him is something which has to be achieved, and not given simply because one is born of human seed" [1984, 172]. The implication of Menkiti's assertion is that, the self or personal identity which an individual comes to possess as a human cannot be made sense of, except by reference to collective consciousness. It further implies that, one attends full personhood or becomes fully human, depending on how long he has been in a community or how old he is. In other words, the older an individual is the more human that individual becomes.

The problem with the communal interpretation of the human person by Mbiti and Menkiti which the idea of Madukaku and the philosophy of Madukakism rejects is the fact that it places the community above the individual. It makes the individual a function of the society in which he lives, such that the individual's rights are assessed in relation to the will of the community. This, not only threatens, but also destroys the individual's self-worth, creativity and ingenuity. What both authors seem to overlook, but which the philosophy and theory of Madukakism takes into cognizance is the fact that, there is no community, state, nation or universe without the individual human person. This is why Plato as quoted by 
Desmond describes the state as "individual write lar7, 4e" [1984], meaning that it is the individuals that make up the state.

The point is that, it takes an individual to agree with another individual to come together in a marital union. This union though primarily, a sexual relation, brings into existence other human beings, thus, forming a family. The family is further enlarged through this same human personal relationship, into kindred, from kindred to communities, states, nations and the universe as a whole. Thus, "the individual is a microcosm" (Onunwa, 1991, 68). The individual is the building block, the foundation or the root of the community that Mbiti and Menkiti were referring to. Without the individual, there is no community and by extension, no universe.

This is why the philosophy of Madukakism places Madukaku at the foundation of human existence. To be human is to be Madukaku and to be Madukaku is to be human. Thus, personhood is not achieved by a human person working towards getting the community to approve of his/her humanness as Mbiti and Menkiti, suggest. Humanity, personhood, humanhood or human existence is a product of the idea of Madukaku, which is a product of the individual worthiness, value, integrity, self-importance, which is his essence. A person is simply human because he is of a human seed and possesses within him/herself that natural tendency and value over non-human aspects of the cosmic environment. This is why Madukaku and the philosophy of Madukakism reject racism, slavery and the projection of one race above another.

According to Jonathan Chimakonam and Lucky Ogbonnaya, in their work "A Conceptual and Contextual Meaning of Mmadu in Igbo Reality Scheme", it is around Mmadu that everything revolves. He/she may not possess all the power required to survive in the dangerous world, but does possess the intellectual wizardry to control all other forces, to use their powers to serve his/her existential needs. This makes Mmadu the ultimate reality in the Igbo universe [2015,271]. In other words, for these scholars, the centrality and importance of Mmadu in the universe cannot be overemphasized, especially as it renders human life as the ultimate reality in Igbo worldview. Now, though the idea of Madukaku as being human affirms the above assertion that since human person is the ultimate reality, his/her absence renders every other thing non-existence and therefore meaningless. However, it disagrees with it on one count, as the theory of Madukakism does not subscribe to the claim that it is the 'intellectual wizardry' which the individual possesses that makes him/her human and therefore supreme over other beings. The idea of Madukaku as the basis of being human projects an individual as having personhood in so far as he/she is of the human seed which naturally bestows on him the supremacy, worthness, importance and value over and above other things.

In fact, to accept the view that a person assumes the status of personhood or humanhood on the basis of possessing intelligence, will power, memory or intellectual wizardry as Chimakonam and Lucky put it, is to place one human person over and above another who may have less of the above quality. Such a criterion will dehumanize some persons. It is this type of reasoning that creates room for: racism, ethnicity, dehumanization, slavery, man's inhumanity to man, terrorism, war, conflicts, discrimination of all kinds and forms and at all levels. These are the very ideas that Madukaku, the basis of Madukakism as the philosophy of being human opposes and seeks to overcome.

Against the conception of an individual, being a human person on the basis of intellectual prowess by Chimakonam and Lucky, and against the communal interpretation of the nature of human person by Mbiti and Menkiti, Kwame Gyekye proposes a normative conception of the human person. From the background of the Akan speaking people of Ghana, Kwame observes that the individual is a person on the basis of his possession of a moral character. According to him, a person is defined in terms of his/her moral qualities or capacities. A human person is a being who has a moral sense and is capable of making moral judgments [1992, 110]. Kwame's assertion suggests that moral qualities such as humility, respect for others, goodness, peace-loving, etc, is what makes a person who possesses them human. Kwame disagree with Menkiti that it is the community which defines the person as person, and not some isolated static quality of rationality, will or memory. For Kwame, a human is a person whatever his age or social status, it is not acquired or yet to be achieved as one goes along in the society. In otherwords, Kwame presents some static quality of morality as that which embodies human beings. Thus, it follows that the acquisition and display of moral virtue by individual is what makes him/her human.

Though Madukakism supports the idea that one is a person because of what he is, not because of what he has acquired, yet it does not subscribe to moral virtue alone as the sole embodiment of what it means to be human. The reason is that, there are many persons who live immorally and amorally, yet they do not cease to be humans. Some persons may not, have the capability for virtuous acts, yet they still remain humans. Another significant aspect of Kwame's analysis of the human person, is his observation that God created everyone to be good, which means that by nature man is good. The implication here is that, inherently and naturally, man possesses good qualities. And these good qualities are interpreted by Kwame to mean moral goodness, which implies that man has the natural tendency to display moral virtues and to make moral choices. Hence, man is a moral agent [1991,102]. The idea of Madukaku as the basis of being human, and its attendant philosophy of Madukakism conceives the human person as not only inherently and naturally good, but also rich in high moral values, greater than and better than every other existing 
things in all ramification. In other words man's worth, dignity, value and humanness transcend communal approval, intellectual wizardry and moral responsiveness. The human person is thus, supreme in him/herself and over other things in the universe.

\section{Summary and Conclusions}

Africa and the world over is in need of peace. The continent is traumatized with numerous crisis, ranging from crisis of identity, and of relevance, crisis for dominion and for supremacy, religious, social and political crisis. Ethnic and tribal conflicts as well as racial bigotry and discrimination at the global level cannot also be overlooked. In the midst of all these, human value, dignity, worth, freedom and self-authenticity are played down. Individuals have become instruments in the hands of fellow individuals. The society is rife with man's inhumanity to man, bloodshed, murder, suicide bombing, terrorist attacks and the destruction of human lives with reckless abandon. This gory state of the human person and humanity have made it even more difficulty to understand what it really means to be human in today's Africa, and the world at large.

It is against this backdrop that Madukakism is articulated as the philosophy and theory of being human. This philosophy is presented as the needed launch pad to restoring human value, dignity and self-image in our world today. If every race, group or persons will recognize humans for who they are, all forms of dehumanization will be eroded. This philosophy is founded on the Igbo idea of Madukaku, which is interpreted to mean humans are greater than riches and wealth. According to the notion of Madukaku, to be human is to be intrinsically worth more than wealth or any possession of material things. It is to be more precious and valuable than anything else. Using the idea of Madukaku as the basis of being human in (Igbo) Africa, Madukakism rejects colonialism, slavery, racism, ethnicity and all forms of discrimination and dehumanization of the human person.

Having examined the views of J. S. Mbiti, Ifeanyi Menkiti, Jonathan Chimakonam and Lucky Ogbonnaya as well as Kwame Gyekye, this work exposes the positive import of their analysis on personhood. However, following the principle of Madukaku upon which Madukakism as the philosophy and theory of being human is formulated. It was argued against Mbiti and Menkiti that individual human person does not exist after and for the society. $\mathrm{He} / \mathrm{she}$ is the bedrock of the society or community. Thus, the human person does not really need the community's approval to be who he/she is. Again, against the views of Chimakonam and Lucky, human being (Madu) is not human solely because of his intellectual prowess. He is much more than that, for to accept that as the basis of being human, is to reduce other humans who may have less of such prowess, to less human. This is against the principle of Madukaku and the philosophy of Madukakism. Moreso, Kwame Gyekye's critique of Menkiti and his brilliant exposition of the moral responsiveness of the individual as the basis of being human was also shown to be in opposition to the philosophy of Madukakism on the ground that capability of virtuous act is not enough basis for being human in contemporary times. For to accept that, again, will imply that those individuals with moral weakness are therefore less human.

On the other hand, the theory of Madukakism identifies with Onunwa's position that a human person is at the centre of the pressures and activities in the universe. Madukaku as the basis of being human presents the individual person as human in so far as he/she is of the seed of human, and as such possesses natural and intrinsic worth or value that transcends intelligence, morality, community and any other limiting feature or quality. Thus, to be human is to be Madukaku and to be Madukaku is to be human.

\section{REFERENCES}

[1] Chielozana, E. (1988). Man as Mmadu: Human Being and Being Human in Igbo Context. West African Journal of Philosophical Studies. 1(1) 27-48.

[2] Chimakonam, J. O. and Lucky, O. A. (2015). Conceptual and Contextual Meaning of "Mmadu" in the Igbo Reality Scheme: further Contribution to Uram Igbo Studies, Uram. 34 (3-4): $268-83$.

[3] Desmond, L. Plato: 1987). The Republic. England: Penguin Books.

[4] Ejiogu, E. A. (2014). The Problematic of Human Dignity in Africa. OWERRI: Living Flames Resources.

[5] Emmanuel, M.P.E. (1998). Towards an Igbo Metaphysics. Chicago: Loyola University Press.

[6] Gyekye, K. (1992). Person and community in African thought. In; Wiredu K and Gyekye K, (ed.). Person and community: Ghanaian Philosophical Studies, I. Washington D.C: Council for Research and Values,. p101 - 122.

[7] Iroegbu, P. (1998). Metaphysics: The Kpim of Philosophy. Owerri: International University Press.

[8] Mbiti, J. S. (1974). African Religions and Philosophy. NewYork: Heinemann Educational.

[9] Menkiti, I. A. (1984). Person and community in African traditional thought. In; Wright R. (ed.). African Philosophy: An Introduction. 2nd ed. New York: University Press of America; p170 - 80.

[10] Odimegwu, I. (2008). Integrative Personhood: A Communalist Metaphysical Anthropology. London: Transaction Publishers.

[11] Onunwa, U. (1991). Humanism: The Bedrock of African Traditional Religion and Culture. Religious Humanism. XXV (2) 66-71. 
[12] Onunwa, U. (1994). The Individual and Community in African Traditional Religion and Culture. The Mankind Quarterly. XXXIV (3) 249-260.

[13] Stumpf, E. S. (1994). Philosophy: History and Problems. NewYork: McGraw-Hill.

[14] Uzukwu, B. (1982). Igbo World and Ultimate Reality and Meaning. Ultimate Reality and Meaning. 5 (3): 188 - 209. 